\title{
Practice and enforcement of national Hospital Waste Management 2005 rules in Pakistan
}

Muhammad Fazal Zeeshan ${ }^{1,2}$, Ahmad Al Ibad ${ }^{1,2}$, Abdul Aziz ${ }^{1,2}$, Aftab Subhani ${ }^{1,2}$, Asif Shah ${ }^{1,2}$, Tahir Khan ${ }^{1,2}$, Hidayat Ullah ${ }^{1,2}$ and Umair Qazi ${ }^{1,2}$

${ }^{1}$ Riphah International University, Islamabad, Pakistan. ${ }^{2}$ Peshawar Medical College, Peshawar, Pakistan (Correspondence to: M.F. Zeeshan: mzeeshan@ piph.prime.edu.pk).

\begin{abstract}
Background: Hospital waste management (HWM) rules in Pakistan were issued in 2005. Despite a decade of enactment, adherence to HWM 2005 rules has been inconsistent and systematic assessment of adherence using a World Health Organization (WHO)-recommended questionnaire has not been done in all teaching hospitals of Peshawar District.

Aims: This study assessed the adherence to HWM 2005 rules by tertiary care teaching hospitals of Peshawar District with respect to HWM personnel, policy and practices.

Methods: Pretested structured questionnaires based on WHO recommendations were used to survey all teaching hospitals of Peshawar District from January to March 2015. Data were also collected on HWM infrastructure and processes from 1 randomly selected medical, surgical, paediatric, and obstetrics/gynaecology unit in each hospital. Besides descriptive statistics, public and private hospitals were compared using Fisher's exact and Wilcoxon rank-sum tests.

Results: Most surveyed hospitals lacked formal HWM plans (70\%), written procedures (80\%), related job descriptions $(80 \%)$ or records $(90 \%)$. Many hospitals neither had trained HWM supervisors $(56 \%)$ nor did they organize formal HWM trainings for new staff $(40 \%)$. None of the hospitals followed waste segregation and colour coding. When compared to national HWM 2005 rules, multiple gaps in appropriate transportation, storage and disposal were found with no statistically significant difference between public and private hospitals.

Conclusions: Serious gaps in adherence to HWM 2005 rules exist in surveyed hospitals. With recent devolution of environmental function, the Government of Khyber Pakhtunkhwa should enact provincial HWM rules (and ensure their implementation) to facilitate effective HWM practice across provincial healthcare facilities.
\end{abstract}

Keywords: Waste management, hospitals, environmental health, World Health Organization, Pakistan

Citation: Zeeshan MF; Al Ibad A; Aziz A; Subhani A; Shah A; Khan T; et al. Practice and enforcement of national hospital waste management 2005 rules in Pakistan. East Mediterr Health J. 2018;24(5):443-450. https://doi.org/10.26719/2018.24.5.443

Received: 22/12/16; accepted: 28/05/17

Copyright (C) World Health Organization (WHO) 2018. Some rights reserved. This work is available under the CC BY-NC-SA 3.0 IGO license (https:// creativecommons.org/licenses/by-nc-sa/3.o/igo).

\section{Introduction}

Hospital waste is generated during patient care and has the potential to cause health and environmental damage (1). Depending upon the spectrum of hospital services, waste includes $10-25 \%$ biohazardous material (such as sharps and chemical, infectious, pharmaceutical, radioactive and genotoxic waste) and 75-90\% nonbiohazardous waste (such as food waste, cardboard and packaging) (2). It is not surprising that hospital waste, if poorly managed, poses a serious threat to neighbouring communities as well as healthcare providers, patients and visitors (3).

In Pakistan, like other developing countries, prior studies have reported poor hospital waste management (HWM) practices (4-6). Studies conducted in major cities in Pakistan (i.e., Karachi, Lahore, Rawalpindi and Islamabad) have consistently reported mismanagement of hospital waste with respect to following segregation techniques and appropriate disposal procedures (7-10). This is alarming as $\sim 0.8$ million tonnes of waste is produced daily from hospitals in Pakistan (11).

To improve HWM, the Government of Pakistan enacted the HWM 2005 rules based on the Pakistan
Environmental Protection Act (PEPA) of 1997 (12). This was the first comprehensive legislation that aimed to achieve sustainable improvements in HWM practices. The HWM 2005 rules reflected the World Health Organization guidelines from establishment of a facilitybased waste management plan (detailing the assignment of responsibilities, management structure, and duties) to effective regulation of onsite collection, segregation, handling, labelling, storage, transportation and disposal of healthcare waste $(12,13)$. In addition, the HWM 2005 rules specified the constitution of an HWM Team and roles of its members, along with outlining a supervisory and advisory mechanism in the form of a Hospital Complaint Scrutiny Committee for each district, and an HWM Advisory Committee at federal and provincial levels (12). After devolution of health, education, environment and other social sectors from the federal to provincial tiers in July 2011, Khyber Pakhtunkhwa Province enacted its own Environmental Protection Act (KPEPA) in December 2014. The HWM rules on the basis of KPEPA 2014 are yet to be developed. However, despite a decade of federal HWM 2005 rules enactment (2005-2014), adherence has been inconsistent $(6,7,9)$ and a systematic formal inspection for 
adherence to HWM 2005 rules by the relevant authorities has not yet been conducted.

The legal and regulatory frameworks for solid waste management are based on the federal and (now) provincial Environment Protection Acts. Apart from constituting the Environmental Protection Agency, the Acts established Environmental Improvement

Funds and Environmental Protection Tribunals, listing the relevant functions, powers, penalties and other procedures. The enforcement of HWM 2005 rules within health facilities is under the domain of the Department of Health, and if hazardous waste is found outside a health facility, the Regional Chapter of the Environmental Protection Agency takes action.

Peshawar is the provincial capital of Khyber Pakhtunkhwa, with an estimated population of 3.7 million and 10 tertiary care teaching hospitals (14). The HWM practices among these hospitals have not been reported as a whole. More specifically, to the best of our knowledge, no recent study has assessed adherence to the HWM 2005 rules after a decade of enactment among all tertiary care teaching hospitals of Peshawar District.

The present study included all tertiary care teaching hospitals (both public and private) of Peshawar District to document their adherence to HWM 2005 rules. We also aimed to identify the existing human resources and infrastructure dedicated to waste management functions within each hospital.

\section{Methods}

This cross-sectional study included all 10 (7 private and 3 public) tertiary care teaching hospitals in Peshawar District, Khyber Pakhtunkhwa Province, Pakistan. Data were collected from January to March 2015 by direct observation using a checklist and a pretested structured questionnaire. The structured questionnaire was based on recommendations by the World Health Organization (13) for evaluation of HWM in developing countries. Data were collected about 3 main domains. 1) HWM-related policy: awareness about HWM 2005 rules, existence of HWM plan, dedicated team, written procedures, record maintenance and HWM-related tasks in job descriptions. 2) HWM-related personnel: dedicated formally trained personnel, and trainings for new and existing HWM staff. 3) HWM-related practices: waste segregation, colour coding, waste handling, use of personal protective equipment (PPE), separate transport for infectious and noninfectious waste, presence of temporary waste storage area, use of internal transport containers and vehicles/media and waste disposal and incinerators. Functionality of the incinerators was assessed among the hospitals where the incinerators were present. The incinerators were considered functional if used regularly by the hospital for waste destruction.

In addition, questionnaires were completed by interviewing management staff, including medical or deputy medical superintendents, and nurses in charge of cleaning staff, incinerator supervisors and other staff relevant to HWM processes.

The HWM-related infrastructure and processes in each hospital were observed by trained data collection staff for 1 medical, surgical, paediatric and obstetrics/ gynaecology unit. Among hospitals with $>1$ unit in a specialty, the observed unit was randomly selected through a simple draw. Descriptive statistics were reported as relevant frequencies, proportions, means and standard deviations. Proportional comparisons between public and private sector tertiary care teaching hospitals for HWM policies, personnel, and practice-related variables were tested for similarity using Fisher's exact tests. The assumption of normality was assessed for HWM staffing levels using the Shapiro-Wilk test. The HWM staffing levels were compared between public and private teaching hospitals using the Wilcoxon rank-sum (Mann-Whitney U) test. The level of significance used for all statistical analyses was 0.05. All analyses were performed using SPSS version 19 software. The study was approved by the Institutional Review Board of the Prime Foundation, Peshawar, Pakistan.

\section{Results}

All 10 surveyed hospitals were general hospitals providing a range of emergency and nonemergency medical and surgical services to adult and paediatric patients. Overall, when compared to private sector tertiary care teaching hospitals, public sectors hospitals of Peshawar District had significantly higher average bed capacity (1367 vs. 272 for private sector hospitals, $P=0.01$ ), average daily new admissions ( 288 vs. $47, P=0.02$ ), outdoor patients (1804 vs. $247, P=0.03)$, and daily major surgical procedures $(69$ vs. $11, P=0.05)$. The summary characteristics of surveyed hospitals are given in Table 1.

\section{HWM policy}

This study determined adherence of surveyed hospitals to HWM rules 2005 in general but more specifically regarding HWM polices, personnel and practice. For HWM polices, the HWM rules 2005 stipulate constitution of a waste management team, development of a waste management plan and written procedures, and weekly record maintenance for quantities of generated waste (12). We found that $40 \%$ of those in charge of HWM in the surveyed hospitals were not aware of the HWM rules 2005 (Table 2). While there was a formal HWM team in $70 \%$ of hospitals, only $30 \%$ of the surveyed hospitals had an HWM plan. Twenty percent of the hospitals had written HWM procedures. Similarly, only $20 \%$ of the surveyed hospitals mentioned HWM-related duties in the job descriptions of the relevant personnel. Ninety percent of the surveyed hospitals had no formal records of the quantity and type of waste that they produced. Most of the hospitals $(60 \%)$ did not allocate a dedicated budget to HWM practices. The study compared the HWM policyrelated indicators among private and public hospitals and found no significant difference (Fisher's exact test, $P>0.05$ ). It is worth mentioning that none of the public 


\begin{tabular}{|c|c|c|c|c|c|}
\hline & & $\begin{array}{c}\text { All surveyed } \\
\text { hospitals } \\
(n=10)\end{array}$ & $\begin{array}{l}\text { Private hospitals } \\
\qquad(n=7)\end{array}$ & $\begin{array}{l}\text { Public hospitals } \\
\qquad(n=3)\end{array}$ & $\begin{array}{l}P \text { Wilcoxon rank- } \\
\text { sum (Mann- } \\
\text { Whitney) test }\end{array}$ \\
\hline \multirow{2}{*}{ Bed capacity } & Mean (SD) & $601(549)$ & $272(105)$ & $1367(255)$ & \multirow{2}{*}{0.01} \\
\hline & Median (IQR) & $330(950)$ & $260(210)$ & $1240(461)$ & \\
\hline \multirow{2}{*}{ Outdoor patients per day } & Mean (SD) & 766 (1000) & $247(132)$ & $1804( \pm 1240)$ & \multirow{2}{*}{0.03} \\
\hline & Median (IQR) & $353(150)$ & $275(243)$ & $2263(2348)$ & \\
\hline \multirow{2}{*}{ New hospital admissions per day } & Mean (SD) & $127(133)$ & $47(33)$ & $288(101)$ & \multirow{2}{*}{0.02} \\
\hline & Median (IQR) & $70(189)$ & $44(50)$ & $250(191)$ & \\
\hline \multirow{2}{*}{ Operating theatre tables } & Mean (SD) & $15(19)$ & $5(2)$ & $40(18)$ & \multirow{2}{*}{0.02} \\
\hline & Median (IQR) & $7(21)$ & $4(4)$ & $37(36)$ & \\
\hline \multirow{2}{*}{ Major operations conducted per day } & Mean (SD) & $29(43)$ & $11(6)$ & $69(67)$ & \multirow{2}{*}{0.05} \\
\hline & Median (IQR) & $13(12)$ & $10(12)$ & $48(128)$ & \\
\hline
\end{tabular}

${ }^{a}$ Median and IQR are also reported, as data do not follow normal distribution.

${ }^{b}$ Even though caution should be used to interpret the $P$ values due to small sample size, the significant $P$ values indicate statistically significant differences between public and private tertiary care teaching hospitals of Peshawar district in terms of basic hospital attributes.

$I Q R=$ interquartile range; $S D=$ standard deviation .

\begin{tabular}{|c|c|c|c|c|}
\hline & $\begin{array}{c}\text { Overall, \% } \\
(n=10)\end{array}$ & $\begin{array}{l}\text { Private hospitals } \\
(n=7), \%\end{array}$ & $\begin{array}{l}\text { Public hospitals } \\
\text { (n=3), } \%\end{array}$ & $\begin{array}{c}\mathbf{P}^{*} \text { (Fisher's exact } \\
\text { test) }\end{array}$ \\
\hline HWM supervisors' awareness about HWM 2005 Rules & 60.0 & 57.1 & 66.7 & 1.00 \\
\hline Existence of HWM plan & 30.0 & 28.6 & 33.3 & 1.00 \\
\hline Presence of formal HWM team & 70.0 & 71.4 & 66.7 & 1.00 \\
\hline Presence of written HWM procedures & 20.0 & 28.6 & 0.0 & 1.00 \\
\hline Record maintenance of hospital waste produced & 10.0 & 14.3 & 0.0 & 1.00 \\
\hline Presence of dedicated HWM budget & 40.0 & 28.6 & 66.7 & 0.50 \\
\hline Documentation of HWM related tasks in job descriptions & 20.0 & 28.7 & 0.0 & 1.00 \\
\hline
\end{tabular}

${ }^{*}$ Even though caution should be used to interpret the P values due to small sample size, the nonsignificant 2-sided Fisher's exact test P values for HWM policy-related variables indicate that nonadherence to HWM 2005 rules is statistically similar in both public and private teaching hospitals of Peshawar District.

HWM = hospital waste management.

hospitals had written HWM procedures, maintained records of hospital waste, or documented HWM-related tasks in job descriptions. The detailed breakdown of HWM policy-related indicators are given in Table 2.

\section{HWM personnel}

Overall, on average, 28 dedicated staff members were responsible for HWM-related activities in each surveyed hospital (Table 3). The number of dedicated HWM staff was significantly greater in public (47) as compared to private (20) hospitals (Wilcoxon rank-sum $P<0.05$ ). When the number of total beds per hospital was taken into account, public hospitals had fewer dedicated HWM staff members (not significant, $P=0.14$ ). Most $(55.6 \%$ ) of the HWM supervisors in the surveyed hospitals had no formal training in HWM (Table 4). In $60 \%$ of the surveyed hospitals, newly hired, lower-grade staff were informally trained about HWM practices by their immediate supervisors. Most of such hospitals $(71.5 \%)$ were private tertiary care teaching hospitals. There was no formal refresher HWM training in public sector hospitals, while $28.6 \%$ of the private hospitals arranged refresher training at monthly to bimonthly intervals.

\section{HWM practices}

HWM-related practices from waste generation to disposal within hospital premises were observed (Table 5). None of the tertiary care teaching hospitals of Peshawar District practiced the prescribed segregation and colour-coding techniques for hospital waste handling. Despite this, $40 \%$ of the hospitals internally transported hazardous waste separately on the basis of waste bin location (i.e., mixed waste from patient wards was considered hazardous, while that from doctors' lounges and other administrative offices was deemed nonhazardous). Since there was no segregation or colour coding, separate internal transport in its true technical sense was also not performed in any of the surveyed hospitals.

Most $(80 \%)$ of the tertiary care hospitals had HWM staff wearing protective gloves. Among those wearing protecting gloves (not shown in Table 5), 66\% wore masks or protective shoes, while half wore aprons. Only $30 \%$ of the tertiary care teaching hospitals had HWM staff wearing all four types of PPE. In public sector hospitals, none of the observed HWM staff wore masks, aprons or protective shoes (Table 5). 


\begin{tabular}{lcccc}
\hline Table 3 Comparison of dedicated HWM staffing among private and public hospitals ( $\mathbf{n}=\mathbf{1 0})$ & & \\
& Overall, mean (SD) & $\begin{array}{c}\text { Private hospitals, } \\
\text { mean (SD) }\end{array}$ & $\begin{array}{c}\text { Public hospitals, } \\
\text { mean (SD) }\end{array}$ & $\begin{array}{c}\text { P (Wilcoxon rank- } \\
\text { sum test) }\end{array}$ \\
Dedicated HWM personnel $^{\mathbf{a}}$ & $28.1(18.2)$ & $20.1(10.2)$ & $46.7(20.8)$ & 0.03 \\
HWM personnel per 10o beds & $6.7(4.2)$ & $8.1(4.2)$ & $3.3(0.9)$ & 0.14 \\
\hline
\end{tabular}

${ }^{a}$ While the number of dedicated HWM personnel is reported here, it is the HWM personnel per 100 beds that reflect the status of HWM staffing in the surveyed hospitals. $H W M=$ hospital waste management; $S D=$ standard deviation .

\begin{tabular}{lcccc}
\hline $\begin{array}{l}\text { Table 4 Study findings related to HWM personnel } \\
\text { HWM personnel variables }\end{array}$ & $\begin{array}{c}\text { Overall, \% } \\
(\mathbf{n}=\mathbf{~ 1 0})\end{array}$ & $\begin{array}{c}\text { Private hospitals, \% } \\
(\mathbf{n}=\mathbf{7})\end{array}$ & $\begin{array}{c}\text { Public hospitals, \% } \\
(\mathbf{n}=\mathbf{3})\end{array}$ & $\begin{array}{c}\boldsymbol{P}^{*} \text { (Fisher's exact } \\
\text { test) }\end{array}$ \\
\hline Formally trained HWM supervisors & 44.4 & 28.6 & 100.0 & 0.17 \\
Formal HWM trainings to new staff & 60.0 & 71.5 & 33.3 & 0.50 \\
Formal HWM refresher trainings to staff & 20.0 & 28.6 & 0.0 & 1.00 \\
\hline
\end{tabular}

*Caution should be used to interpret the P values due to small sample size.

HWM $=$ hospital waste management.

\begin{tabular}{|c|c|c|c|c|}
\hline HWM practices & $\begin{array}{c}\text { Overall, \% } \\
(n=10)\end{array}$ & $\begin{array}{c}\text { Private hospitals, } \\
\% \\
(n=7)\end{array}$ & $\begin{array}{c}\text { Public hospitals, } \\
\% \\
(n=3)\end{array}$ & $\begin{array}{c}P^{*} \\
\text { (Fisher's exact } \\
\text { test) }\end{array}$ \\
\hline Waste segregation & 0.0 & 0.0 & 0.0 & - \\
\hline Colour coding & 0.0 & 0.0 & 0.0 & - \\
\hline \multicolumn{5}{|l|}{ Waste handling, storage and transport } \\
\hline \multicolumn{5}{|l|}{ Use of personal protective equipment } \\
\hline Gloves (surgical or thick) & 80.0 & 85.7 & 66.7 & 1.00 \\
\hline Face masks & 40.0 & 57.1 & 0.0 & 0.20 \\
\hline Plastic aprons & 30.0 & 42.9 & 0.0 & 0.48 \\
\hline Protective shoes/long boots & 40.0 & 57.1 & 0.0 & 0.20 \\
\hline Presence of temporary waste storage area & 90.0 & 85.7 & 100.0 & 1.00 \\
\hline Restricted access to temporary storage area & 20.0 & 28.6 & 0.0 & 1.00 \\
\hline At least once monthly disinfection of temporary storage area & 40.0 & 57.1 & 0.0 & 0.20 \\
\hline \multicolumn{5}{|l|}{ Internal transport containers } \\
\hline Plastic bags & 20.0 & 28.6 & 0.0 & 1.00 \\
\hline Containers with lids & 40.0 & 42.9 & 33.3 & 1.00 \\
\hline Containers without lids & 50.0 & 42.9 & 66.7 & 1.00 \\
\hline \multicolumn{5}{|l|}{ Internal transport vehicles/medium } \\
\hline Trolley (3 or 4 wheels) & 20.0 & 14.3 & 33.3 & 1.00 \\
\hline Carts/wheelbarrows (1 or 2 wheels) & 60.0 & 57.1 & 66.7 & 1.00 \\
\hline Manually carrying bags/by hand & 60.0 & 71.4 & 33.3 & 0.50 \\
\hline \multicolumn{5}{|l|}{ Waste disposal } \\
\hline \multicolumn{5}{|l|}{ Incinerators } \\
\hline Present & 70.0 & 57.1 & 100.0 & 0.48 \\
\hline Functional $(\mathrm{n}=7)$ & 71.4 & 100.0 & 33.3 & 0.14 \\
\hline
\end{tabular}

*Caution should be used to interpret the $P$ values due to small sample size. $H W M=$ hospital waste management.

A temporary waste storage area was present in $90 \%$ of the surveyed hospitals (Table 5). Overall, only $40 \%$ regularly disinfected the storage area (frequency ranged from daily to once monthly). Eighty percent of the temporary waste storage areas were open to anyone and had no restricted access (HWM 2005 rules specify that the designated waste storage facility should be totally enclosed and secure from unauthorized access).

Regarding containers for internal transportation of hospital waste, $20 \%$ of the surveyed hospitals were using plastic bags, $40 \%$ were using containers with lids, while 50\% had containers without lids (Table 5). 
The proportions were not mutually exclusive as some hospitals were using multiple types of internal transport containers. For internal transportation media or vehicles, $20 \%$ of hospitals were only using a 3 - or 4-wheel trolley, $20 \%$ had only 1 - or 2 -wheel carts or wheelbarrows, while in $20 \%$ hospital waste was transported only by hand (i.e., manually lifted by HWM staff). It is important to note that some hospitals were using more than one means of internal transportation of hospital waste. For instance, $40 \%$ of the hospitals were using both 1- or 2-wheel carts/wheelbarrows and manual lifting for internal transportation.

Eighty percent of the tertiary care teaching hospitals (100\% public vs. $57.1 \%$ private) had incinerators and $71.4 \%$ of them were functional (Table 5). The nonfunctional incinerators belonged to public sector tertiary care teaching hospitals. The incinerators were considered functional if they were used regularly by the hospital for waste destruction. Assessment of the technical and procedural details of the incineration process, including recording the exact temperatures and discharged gases, was considered beyond the scope of the present study. Autoclaves were neither present nor used for waste treatment by any of the surveyed hospitals.

\section{Discussion}

This study assessed HWM-related policies, personnel and practice of all tertiary care teaching hospitals in Peshawar District for adherence to national HWM 2005 rules. There was an alarming gap between HWM at surveyed hospitals and the requirements prescribed in HWM 2005 rules.

To align HWM policy and practice, the HWM 2005 rules in Pakistan specify constitution and responsibilities of HWM teams, along with the development of an HWM plan (12). We found that while most of the surveyed hospitals had formal HWM teams, most did not have HWM plans, written HWM procedures, or records of hospital waste produced. An alarming finding was that none of the public hospitals had written HWM procedures, maintained records of hospital waste produced, or had any documentation of HWM-related tasks in job descriptions. Similar findings have been reported previously by studies performed elsewhere in Pakistan and other developing countries $(7,8,15,16,17)$. This may reflect the poor HWM training of senior and mid-level hospital management, lack of managerial commitment towards an organized and documented HWM system, and/or poor regulatory role of government, especially in public hospitals. Our study also found that the overall number of dedicated HWM staff per 100 beds was about 7 in surveyed hospitals, which is especially low if waste handling and transportation is mostly done manually, or using small carts/wheelbarrows. The number of HWM staff per 100 beds was even lower for public sector hospitals ( 3 vs. 8 in private hospitals). This, along with higher inpatient flow and number of daily surgical procedures, lack of proper means for waste handling and transportation, absence of regulating inspections for compliance, and lack of a minimum dedicated HWM budget, may explain the limited capacity of the public hospitals to follow the HWM 2005 rules.

We identified absence of formal HWM training sessions for healthcare workers in many surveyed hospitals. Most of the newly hired workers in such hospitals were informally coached by their immediate supervisors and peers over a period of time. The lack of formal HWM training has also been reported previously in other cities in Pakistan $(8,9,18)$. Besides the overall limited commitment to HWM, the lack of institutional training mechanisms is expected to result from an absence of a comprehensive HWM plan, written procedures, and/ or sufficient budget allocation (and expense) to HWM practices. The HWM training of all healthcare workers in general, and hospital waste handlers in particular, has been shown to be an important prerequisite for better waste management practices $(19,20)$. We believe that HWM training should be standardized and repeated at regular intervals across the provincial healthcare facilities. To improve HWM practices, training must accompany senior management's explicit commitment, with adequate structural and financial support.

We found major gaps at every step of HWM systems, starting from waste segregation and colour coding at the point of care, to handling, storage, transportation and disposal. HWM staff in the surveyed hospitals did not use all the required PPE during waste handling and transport. Similar results have been reported from elsewhere in Pakistan $(8,9)$. Studies have also frequently shown the link between lack of PPE use and the risk of exposure to blood and blood-contaminated body fluids and disease contraction among HWM staff (15, 21-23). The likelihood of an accidental prick is higher if the waste transport is mostly done manually, using open containers or plastic bags, and especially with unsegregated waste in which an empty juice box may lie next to a used infected sharp, as was found in our study. Weak oversight on the part of hospital management, and lack of regulatory commitment from government institutions (departments of health and environmental protection, and city administrations) and patients' and healthcare workers' rights activists are reflected through the use of varying types of containers or vehicles/media for internal transport of waste, inconsistent use of PPE among HWM staff members, and unrestricted access to temporary waste storage sites along with their infrequent disinfection.

Most of the surveyed hospitals were located in densely populated neighbourhoods. Using incinerators for hospital waste disposal risks environmental pollution in neighbouring residential areas (24). However, despite the controversies regarding the use of incinerators (24,25), when assessed for adherence to HWM 2005 rules, the surveyed hospitals had either no incinerator present or a nonfunctioning incinerator. In both cases, it meant that the hospital waste was either treated as domestic waste and disposed by the city waste disposal company, or sent for recycling. Hospitals and other health 
institutions producing potentially biohazardous waste remain responsible for any hazards that their waste may cause in the community. Earlier studies have reported local hospitals' practices related to selling used sharps, injection syringes and other plastic waste $(8,26,27)$. In our study, one large public sector hospital attributed its incinerator nonfunction to the inadequate gas supply from the city gas department. Other hospitals with nonfunctional incinerators had equipment maintenance issues. It is worth mentioning that the final disposal of the hospital waste from all the surveyed hospitals (with or without functional incinerators) was carried out using the municipal solid waste disposal services. The fact that none of the surveyed hospitals treated their healthcare waste using autoclaves exacerbated the management challenge for the municipal waste disposal staff. The lack of adhering to proper disposal protocols in our study was similar across both public and private hospitals.

Our study had some limitations. The study only included tertiary care teaching hospitals in Peshawar District. The study did not include other nontertiary public and private hospitals of varying bed size.

\section{Conclusion}

This is believed to be the first study in Khyber Pakhtunkhwa Province to evaluate adherence to HWM 2005 rules implemented nationally more than a decade ago. This study highlights the lack of adherence to national HWM 2005 rules by all the tertiary care teaching hospitals in Peshawar District. There is an urgent need for the implementation of the HWM 2005 rules by the hospitals and other healthcare facilities. The government authorities should play a leading role by supporting healthcare providers with development of HWM teams and plans, creation of standardized HWM training modules, and establishment of frequent monitoring of their HWM practices. An integrated city-wide medical waste disposal mechanism may prove useful to reduce the current waste burden on large hospitals. Services of such integrated medical waste disposal procedures should also be extended to other small hospitals, clinics and laboratories.

\section{Recommendations}

In view of multiple gaps in the HWM practices highlighted by this study, we make the following recommendations.
1. Establish a centralized district-wide integrated HWM mechanism. The advantages of a central mechanism may include the following.

a. Cost savings on establishing, running and maintenance of the hospital waste disposal equipment and staff.

b. Appropriate waste disposal in locations far from residential areas. Over the past 2 decades, most of the health facilities have clustered in few areas of Peshawar District and are located close to residential areas. Any incinerator-based disposal of hospital waste risks deteriorating the air quality for the nearby residential areas. The centralized HWM mechanism will ensure that the disposal is done far from residential areas.

c. Installation of well-functioning high-temperature incinerators with adequate capacity that can efficiently cater for all the HWM needs of the district.

2. Allocation of a predetermined percentage of total hospital funds on practices related to HWM, especially for public sector hospitals.

3. Training and capacity building of HWM-related staff should be led by the Department of Health. The Department should develop and implement uniform HWM training programmes, followed by third party evaluations to identify the level of adherence in health facilities. The Department should also provide guidance related to PPE, transport equipment, containers, disinfection and sterilization materials, and training manuals. Lastly, the management of the individual health facilities should be held accountable for implementing regular effective HWM trainings of their staff.

4. A functional health inspection mechanism should be created that facilitates regular inspections and evaluations, and provides feedback for legal and regulatory compliance to respective health facilities. This may require a supplementary provincial legal framework in the form of provincial HWM rules based on KPEPA 2014 and/or amending the existing healthcare regulatory mechanisms (e.g., Provincial Health Care Commission that regulates all healthcare services) with appropriate HWM-related requirements. The hospital management must have a regular internal inspection and evaluation mechanism as they hold the primary responsibility towards implementation of all internal and external regulatory requirements.

\section{Funding: None.}

Competing interests: None declared.

\section{Pratiques et application des réglementations nationales en matière de gestion des déchets hospitaliers 2005 : étude de cas au Pakistan}

\section{Résumé}

Contexte : Les réglementations en matière de gestion des déchets hospitaliers au Pakistan ont été publiées en 2005. Dix ans après leur adoption, l'observation des réglementations de 2005 en matière de gestion des déchets hospitaliers demeure incohérente, et une évaluation systématique de la conformité à l'aide d'un questionnaire recommandé par l'Organistation 
mondiale de la Santé (OMS) n'a pas été effectuée dans tous les hôpitaux universitaires du district de Peshawar (Khyber Pakhtunkhwa).

Objectif : La présente étude a évalué l'observation des réglementations de 2005 en matière de gestion des déchets hospitaliers par les hôpitaux universitaires de soins tertiaires dans le district de Peshawar eu égard au personnel, aux politiques et aux pratiques de gestion des déchets hospitaliers.

Méthodes : Des questionnaires structurés prétestés reposant sur les recommandations de l'OMS ont été utilisés pour enquêter dans tous les hôpitaux universitaires du district de Peshawar entre janvier et mars 2015. Des données ont également été recueillies sur les infrastructures et les processus de gestion des déchets hospitaliers auprès de départements de médecine, de chirurgie, de pédiatrie, de gynécologie/d'obstétrique sélectionnés de façon aléatoire dans chaque hôpital. Outre les statistiques descriptives, les hôpitaux publics et privés ont été comparés à l'aide du test exact de Fisher et du test des rangs signés de Wilcoxon.

Résultats : La plupart des hôpitaux enquêtés n'avaient pas de plans officiels (70\%), de procédures écrites (80\%), de descriptifs de postes associés ( 80 \%) ou de dossiers $(90 \%$ pour la gestion des déchets hospitaliers. De nombreux hôpitaux n'avaient pas formé de responsables en gestion des déchets hospitaliers ( $56 \%$ ), ou organisé de formations officielles dans le domaine pour les nouveaux membres du personnel (40\%). Aucun des hôpitaux ne procédait à un tri des déchets ou n'appliquait le code couleurs. Eu égard aux réglementations nationales en matière de gestion des déchets hospitaliers, des lacunes multiples en matière de transports, d'entreposage et d'élimination appropriés ont été révélées, sans différences significatives entre les hôpitaux publics et privés.

Conclusions : Il existe de sérieuses lacunes concernant le respect des réglementations de 2005 en matière de gestion des déchets hospitaliers dans les hôpitaux ayant fait l'objet de l'enquête. Au vu de la décentralisation récente de la gestion environnementale, le gouvernement de Khyber Pakhtunkhwa devrait adopter des réglementations en matière de gestion des déchets hospitaliers à l'échelle de la province (et garantir leur application) afin de faciliter la mise en place de pratiques efficaces de gestion des déchets hospitaliers au sein des établissements de soins de santé dans la province.

$$
\begin{aligned}
& \text { محارسات وتنفيذ القو اعد الوطنية لإدارة نفاقات المستشفيات لعام ه • · ب في باكستان } \\
& \text { محمد فضل ذيشان، أحمد العباد، عبد العزيز، افتاب سبحاني، آصف شاه، طاهر خان، هداية الله، عمير قاضي }
\end{aligned}
$$

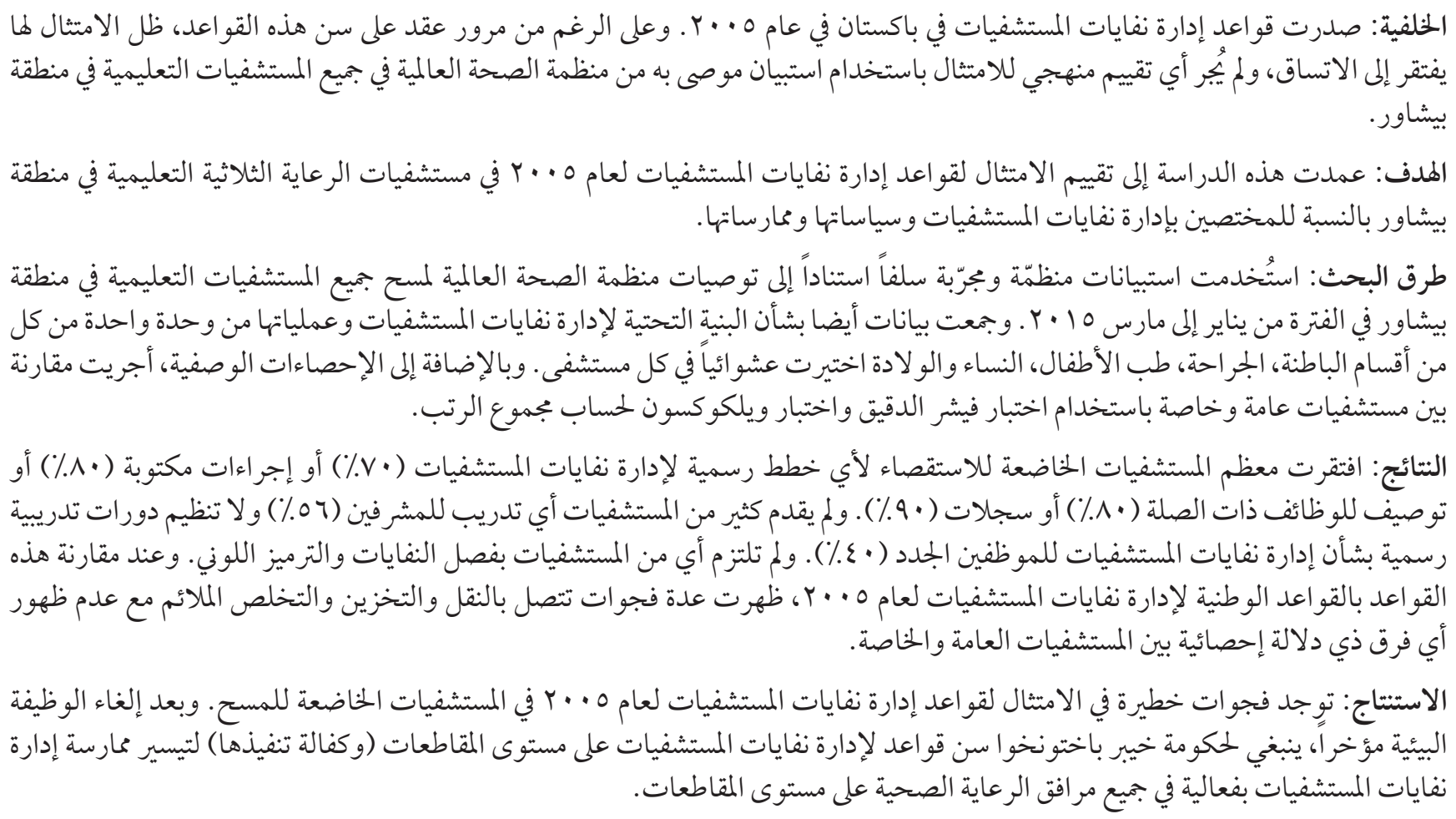

\section{References}

1. Etusim P, Ijere A, Melariri P, Ogwo P, Ikonne U. A study on solid waste generation and characterization in some selected hospitals in Okigwe, Imo State-Nigeria. J Educ Soc Res. 2013 Jul;3(4):37-43. http://dx.doi.org/10.5901/jesr.2013.v3n4p

2. Patil GV, Pokhrel K. Biomedical solid waste management in an Indian hospital: a case study. Waste Manage. 2005;25(6):592-9. 
3. Gupta S, Boojh R. Report: biomedical waste management practices at Balrampur Hospital, Lucknow, India. Waste Manag Res. 2006 Dec;24(6):584-91. http://dx.doi.org/10.1177/0734242X06068342 PMID:17253005

4. Farzadkia M, Moradi A, Mohammadi MS, Jorfi S. Hospital waste management status in Iran: a case study in the teaching hospitals of Iran University of Medical Sciences. Waste Manag Res. 2009 Jun;27(4):384-9. http://dx.doi. org/10.1177/0734242X09335703 PMID:19487312

5. Hageman JP. Handling, storage, treatment, and disposal of mixed wastes at medical facilities and academic institutions. Health Phys. 2002 May;82(5) Suppl:S66-76. http://dx.doi.org/10.1097/00004032-200205001-00007 PMID:12003031

6. Ali S, Mahmood U, Malik AU, Aziz F, Naghman RB, Ahmed I. Current hospital waste management practices in Pakistan: case study and curative measures. Public Health Prevent Med. 2015 Aug;1(3):125-9. http://files.aiscience.org/journal/article/ html/70260042.html

7. Khattak FH. Hospital waste management in Pakistan. Pak J Med Res. 2009 Jan-Mar;48(1):19-23.

8. Rasheed S, Iqbal S, Baig LA, Mufti K. Hospital waste management in the teaching hospitals of Karachi. J Pak Med Assoc. 2005 May;55(5):192-5. PMID:15960283

9. Kumar R, Khan EA, Ahmed J, Khan Z, Magan M, Nousheen A, et al. Healthcare waste management (HCWM) in Pakistan: current situation and training options. J Ayub Med Coll Abbottabad. 2010 Oct-Dec;22(4):101-5. PMID:22455273

10. Rohra DK, Jawaid A, Rehman T, Sukkurwala AQ, Palanpurwala AS, Gangwani R, et al. Waste disposal of government health-care facilities in urban area of Karachi-A KAP Survey. Pak J Med Res. 2007;46(1):5-10.

11. Khan JA. Hospital waste management issues and steps taken by the Government of Pakistan Oct 2006 (http://www.env.go.jp/ recycle/3r/en/asia/02_03-2/04.pdf, accessed 16 January 2018).

12. Hospital Waste Management Rules, 2005. Ministry of Environment, Government of Pakistan; 2005 (http://www.environment. gov.pk/act-rules/rHWMRules2005.PDF, accessed 16 Jaunary 2018).

13. Prüss A, Giroult E, Rushbrook P (editors). Safe management of wastes from health-care activities. Geneva: World Health Organization; 1999 (http://apps.who.int/iris/bitstream/10665/42175/1/9241545259.pdf, accessed 16 January 2018).

14. Khyber Pakhtunkhwa in Figures 2015. Bureau of Statistics, Government of Khyber Pakhtunkhwa; 2015 (http://kpbos.gov.pk/ files/1456999405.pdf, accessed 16 January 2018)

15. Camacho-Ortiz A, Díaz-Rodríguez X, Rodríguez-López JM, Martínez-Palomares M, Palomares-De la Rosa A, Garza-Gonzalez E. A 5-year surveillance of occupational exposure to bloodborne pathogens in a university teaching hospital in Monterrey, Mexico. Am J Infect Control. 2013 Sep;41(9):e85-8. http://dx.doi.org/10.1016/j.ajic.2013.01.008 PMID:23523519

16. Abdulla F, Qdais HA, Rabi A. Site investigation on medical waste management practices in northern Jordan. Waste Manage. 2008;28(2):450-8.

17. Patil AD, Shekdar AV. Health-care waste management in India. J Environ Manage. 2001 Oct;63(2):211-20. http://dx.doi.org/10.1006/ jema.2001.0453 PMID:11721600

18. Imdad S, Anwar S, Shoukat MS. Healthcare waste: evaluation of its generation rate and management practices in tertiary care hospitals of Lahore. Ann King Edward Med Univ. 2013 Oct-Dec;19(4):274-81 (https://doi.org/10.21649/akemu.v19i4.527, accessed 16 January 2018).

19. Kumar R, Somrongthong R, Shaikh BT. Effectiveness of intensive healthcare waste management training model among health professionals at teaching hospitals of Pakistan: a quasi-experimental study. BMC Health Serv Res. 201502 28;15(1):81. http:// dx.doi.org/10.1186/s12913-015-0758-7 PMID:25889451

20. Sapkota B, Gupta GK, Mainali D. Impact of intervention on healthcare waste management practices in a tertiary care governmental hospital of Nepal. BMC Public Health. 2014 Sep 26;14(1):1005. http://dx.doi.org/10.1186/1471-2458-14-1005 PMID:25261099

21. Mol MP, Gonçalves JP, Silva EA, Scarponi CF, Greco DB, Cairncross S, et al. Seroprevalence of hepatitis B and C among domestic and healthcare waste handlers in Belo Horizonte, Brazil. Waste Manage Res. 2016 Sep;34(9):875-83. http://dx.doi. org/10.1177/0734242X16649686 PMID:27207769

22. Ream PSF, Tipple AFV, Barros DX, Souza ACS, Pereira MS. Biological risk among hospital housekeepers. Arch Environ Occup Health. 2016;71(2):59-65. http://dx.doi.org/10.1080/19338244.2014.927347 PMID:25136771

23. Shiferaw Y, Abebe T, Mihret A. Sharps injuries and exposure to blood and bloodstained body fluids involving medical waste handlers. Waste Manag Res. 2012 Dec;30(12):1299-305. http://dx.doi.org/10.1177/0734242X12459550 PMID:22964471

24. Thornton J, McCally M, Orris P, Weinberg J. Hospitals and plastics. Dioxin prevention and medical waste incinerators. Public Health Rep. 1996 Jul-Aug;111(4):298-313. PMID:8711095

25. Chaerul M, Tanaka M, Shekdar AV. A system dynamics approach for hospital waste management. Waste Manage. 2008;28(2):442-9.

26. Mahmood SS, Malik R, Azim W. A study of waste generation, collection and disposal in a tertiary hospital in Pakistan. Pak J Med Res. 2001;40(1):13-7.

27. Abdul Mujeeb S, Adil MM, Altaf A, Hutin Y, Luby S. Recycling of injection equipment in Pakistan. Infect Control Hosp Epidemiol. 2003 Feb;24(2):145-6. http://dx.doi.org/10.1086/502175 PMID:12602701 